\title{
Distal Intestinal Obstruction Syndrome requiring Laparotomy and Instillation of $\mathrm{N}$-Acetylcysteine
}

\author{
Dan W Parrish, Michael D Hermann, Rao R Ivatury, Rahul J Anand
}

\begin{abstract}
A 25-year-old female with long-standing CF and history of previous abdominal operation presented for sinus surgery. Postoperatively, she developed abdominal distention and was initially diagnosed with opiate-induced bowel dysfunction versus adhesive small bowel obstruction (SBO). Subsequent CT-scan and surgical consultation established the diagnosis of distal intestinal obstruction syndrome (DIOS). Conservative management consisting of trial of NPO, fluids, nasogastric suction and polyethylene glycol failed. The patient was taken to the operating room where findings were significant for decompressed distal small bowel starting in mid jejunum. An angiocatheter needle was inserted into proximal dilated bowel after placement of silk purse-string suture. $4 \% \mathrm{~N}$-acetylcysteine (NAC) solution was made with dilution with normal saline. $120 \mathrm{ml}$ of NAC was injected into the bowel, resulting in immediate softening of the obstructing mucus plug. This allowed for the plug to be milked into the colon, and for mucus to be suctioned out of a proximal enterotomy. Postoperatively, the patient received $10 \mathrm{ml}$ of $10 \%$ NAC through nasogastric tube every 6 hours. She was transferred to pediatric pulmonology on postoperative day eight and discharged postoperative day fifteen.
\end{abstract}

Keywords: Bowel obstruction, Cystic fibrosis.

How to cite this article: Parrish DW, Hermann MD, Ivatury RR, Anand RJ. Distal Intestinal Obstruction Syndrome requiring Laparotomy and Instillation of N-Acetylcysteine. Panam J Trauma Critical Care Emerg Surg 2012;1(3):204-205.

Source of support: Nil

Conflict of interest: None declared

\section{ABSTRACTO}

Una paciente de 25 años con historia de fibrosis quística (FQ) de larga y previas cirugías intra-abdominales, data se presentó al hospital para obtener cirugía de senos paranasales. Durante el postoperatorio desarrolló distensión abdominal y fue diagnosticada inicialmente con la disfunción intestinal inducida por opiáceos versus obstrucción de intestino delgado adhesivo (SBO). Posteriormente una Tomografía computarizada (TC) diagnostica y consulta quirúrgica establecieron el diagnóstico de Síndrome de Obstrucción Intestinal Distal. Después de un tratamiento no operatorio fallido, la paciente fue llevada a la sala de operaciones. Durante la exploración quirúrgica yeyuno medio y el intestino distal estaban descomprimidos. Una aguja de angiocatéter fue insertada en intestino proximal dilatado después de la colocación de sutura en jareta seda. $120 \mathrm{mls}$ de $4 \%$ Solución de N-acetilcisteína (NAC se inyectó en el intestino, dando como resultado inmediato de ablandamiento del tapón del moco obstructivo. Las enterotomías fueros cerradas con sutura. Durante el periodo postoperatorio, el paciente recibió $10 \mathrm{ml} 10 \%$ NAC a través de sonda nasogástrica cada 6 horas. La paciente fue trasladada a Neumología pediátrica una semana después de la cirugía, y mandada a la casa en estables condiciones quince días después del procedimiento.

Palabras claves: Obstrucción intestinal, Fibrosis quistica.

\section{INTRODUCTION}

Meconium ileus is a significant cause of bowel obstruction almost exclusive to neonates with cystic fibrosis. Meconiumileus equivalent, now termed distal intestinal obstructive Syndrome (DIOS), was first examined by Jensen in 1962 in an effort to describe meconium-ileus like symptoms in an older child with cystic fibrosis. ${ }^{1}$ DIOS refers to obstruction by inspissated fecal material usually in the terminal ileum of the small intestine.

Currently, DIOS is further classified by the European Society for Pediatric Gastroenterology, Hepatology and Nutrition (ESPGHAN) working group into complete and incomplete DIOS based on the degree of obstruction. The syndrome may present with symptoms consistent with bowel obstruction as well as a possible palpable mass in the right iliac fossa. The mass is often seen on abdominal radiograph. Differential diagnosis can include constipation, appendicitis, Crohn's disease and intussusception. ${ }^{4}$

This case is important as the patient developed DIOS while hospitalized for an unrelated reason. Early recognition of the disease allowed for adequate treatment with an $\mathrm{N}$-acetylcysteine infusion during the surgery.

\section{CASE REPORT}

The patient was a 25-year-old Caucasian female with diagnosed cystic fibrosis since 6 months of age. Other pertinent medical history included a previous $\mathrm{C}$-section. The patient was currently in the hospital for a cystic fibrosis exacerbation 29 days previously. Six days prior to surgery the patient experienced signs of small bowel obstruction including distension, emesis and obstipation. Inciting events likely included opioid-induced ileus followed by withholding of pancreatic enzymes six days prior to surgery.

Prior to surgery, the patient was treated conservatively with laxatives, bowel rest, intravenous fluids and nasogastric suction. Nasogastric suction was initially not performed due to previous sinus surgery. Given the combination of risk factors, the patient's diagnosis was unclear at the time of presentation. The premier items on the differential included simple small bowel obstruction (due to adhesions or other etiology) and DIOS. A barium enema demonstrated a patent colon with stool present. CT scan demonstrated small bowel obstruction with likely DIOS.

After initial laparotomy and lysis of adhesions, the small intestine transition point and the meconium plug 
were isolated. Milking the meconium distally resulted in a small serosal tear distal and proximal to the obstruction. The decision was made to use the proximal serosal tear as the introduction point for an angiocath needle and $\mathrm{N}$-acetylcysteine.

A mixture was made of $30 \mathrm{ml}$ of $20 \% \mathrm{~N}$-acetylcysteine diluted in $200 \mathrm{cc}$ of normal saline for a final dilution of $4 \%$. An angiocatheter was inserted into the proximal serosal tear and into the bowel lumen. A 10cc syringe was used to inject the NAC/saline mixture into the bowel lumen with immediate softening of the proximal obstruction. Much of the meconium was milked distally toward the terminal ileum. A red rubber catheter was inserted into the bowel lumen to get the mixture further downstream. A total of $120 \mathrm{cc}$ of the mixture was introduced with softening of the meconium but not complete resolution, so an enterotomy was made at the proximal serosal tear and manually remove the meconium. All palpable pieces of meconium were removed manually or suctioned out.

Immediately postoperatively, the patient had no issues other than postoperative pain. The patient was given $10 \mathrm{ml}$ of $10 \% \mathrm{~N}$-acetylcysteine through her nasogastric tube every 6 hours to prevent recurrence of the obstruction. Hydration and electrolytes were monitored as well, and the patient suffered no postoperative complications. She was transferred to pediatric pulmonology on postoperative day eight and discharged from the hospital postoperative day fifteen.

\section{DISCUSSION}

The current frequency of DIOS has been recently cited to be 6.2 episodes per 1,000 patient years with a mean age of nine years (rage $0.1-17.9$ years). ${ }^{2}$ The cause in older children and adults is not only due to pancreatic insufficiency but also due to the pathology of cystic fibrosis. Pathological examination demonstrates mucoid plugging of the crypts with a thick layer of mucous that adheres to the surface among other findings. ${ }^{3}$ Since the mass is strongly connected to the crypts and villi, it becomes difficult to move. ${ }^{4}$

Risk factors include a severe genotype, pancreatic insufficiency, history of meconium ileus and a history of DIOS among others. ${ }^{2}$ Current treatment of DIOS is varied as there is little evidence to support a single treatment algorithm. However, it commonly begins with nonoperative management with agents that can dissolve the inspissated fecal material or induce an osmotic shift of water into the small intestine. These agents include sodium meglumine diatrizoate (gastrografin), polyethylene glycol laxatives, and oral $\mathrm{N}$-acetylcysteine. ${ }^{2,4}$ Additional conservative measures are similar to the management of small bowel obstruction and may include nasogastric suction, bowel rest and intravenous fluids. In adults, enterotomy is recommended before small bowel resection as the fecal material can be removed through the enterotomy. In addition, an enterotomy with instillation of NAC or pancreatic enzymes allows non-compromised bowel to be preserved rather than being resected. ${ }^{5}$ Prophylaxis of DIOS includes laxative therapy, lactulose, hydration, and evaluation of pancreatic enzyme dosage. $^{4}$

\section{CONCLUSION}

The diagnosis of DIOS in the CF patient can be elusive. Withholding pancreatic enzymes may contribute to development of disease. Intraoperative instillation of NAC can be useful in patients failing conservative therapy.

\section{REFERENCES}

1. Jensen K. Meconium-ileus equivalent in a 15-year-old patient with mucoviscidosis. Acta Paediatr 1962;51:344-48.

2. Houwen R, van der Doef H, Sermet I, et al. Defining DIOS and constipation in cystic fibrosis with a multicentre study on the incidence, characteristics, and treatment of DIOS. J Pediatr Gastroenterol Nutr 2010;50:38-42.

3. Jeffrey I, Durrans D, Wells M, Fox H. The pathology of meconium ileus equivalent. J Clin Pathol 1983;36:1292-97.

4. Colombo C, Ellenmunter H, Houwen R, et al. Guidelines for the diagnosis and management of distal intestinal obstructive syndrome in cystic fibrosis patients. Journal of Cystic Fibrosis 2011;10:S24-28.

5. Speck K, Charles A. Distal intestinal obstructive syndrome in adults with cystic fibrosis. Archives of Surgery 2008;143(6): 601-03.

\section{ABOUT THE AUTHORS}

\section{Dan W Parrish}

Surgical Resident, Department of Surgery, Virginia Commonwealth University, Virginia, USA

\section{Michael D Hermann}

Medical Student, Virginia Commonwealth University, Richmond Virginia, USA

\section{Rao R Ivatury}

Professor, Department of Surgery, Division of Trauma, Virginia Commonwealth University, Richmond, Virginia, USA

\section{Rahul J Anand (Corresponding Author)}

Assistant Professor, Department of Surgery, Division of Trauma, Critical Care and Emergency Surgery, Virginia Commonwealth University, West Hospital, 15th Floor, East Wing, 1200 East Broad Street, PO Box 980454, Richmond, VA 23298-0454, USA, Phone: 804 827-1203, Fax: 804 827-0285, e-mail: ranand@mcvh-vcu.edu 